\title{
Nuclear data needs within the US Nuclear Criticality Safety Program
}

\author{
R.D. McKnight ${ }^{1, a}$, M.E. Dunn ${ }^{2}$, R.C. Little ${ }^{3}$, J.R. Felty ${ }^{4}$, and J.N. McKamy ${ }^{5}$ \\ 1 Argonne National Laboratory, Argonne, IL, USA \\ 2 Oak Ridge National Laboratory, Oak Ridge, TN, USA \\ 3 Los Alamos National Laboratory, Los Alamos, NM, USA \\ 4 SAIC, Washington, DC, USA \\ ${ }^{5}$ US Department of Energy, Washington, DC, USA
}

\begin{abstract}
This paper will present the nuclear data needs currently identified within the US Nuclear Criticality Safety Program (NCSP). It will identify the priority data needs; it will describe the process of prioritizing those needs; and it will provide brief examples of recent data advances which have successfully addressed some of the priority criticality safety data needs.
\end{abstract}

\section{Introduction}

The US Department of Energy Nuclear Criticality Safety Program (NCSP) maintains fundamental infrastructure that supports operational criticality safety programs. Important elements of that infrastructure include integral experiments, nuclear data, benchmarking, and methods and codes. Support for the nuclear data program element performs cross section measurements, data evaluations and data validation to meet priority data needs. Support for measurements is primarily to the Oak Ridge Electron Linear Accelerator (ORELA). Support for evaluation is primarily to ORNL for the resonance region and to LANL for above the resonance region. Support for validation is primarily to LANL and ANL. In each of these areas (measurement, evaluation and validation) the NCSP support is often leveraged through multi-laboratory or international collaborative efforts. Recent examples abound, e.g., ORNL collaboration with IRMM on measurements of Mn performed at Geel, the IAEA Coordinated Research Project (CRP) producing new complete evaluations for ${ }^{232} \mathrm{Th},{ }^{231} \mathrm{~Pa}$ and ${ }^{232} \mathrm{~Pa}$, and the outstanding contributions to the validation effort for the ENDF/B-VII data files from NRG Petten.

In 2002 the NCSP Nuclear Data Advisory Group (NDAG) was formed to optimize the limited DOE NCSP resources to address and meet the data needs of operational criticality safety. The NDAG has established a procedure to harvest the data requests from the criticality safety (CS) community, to identify the specific resource (integral measurements, differential measurements, benchmarks, or evaluations) required to meet that need, to prioritize the data needs, and to shepherd the work to completion to meet those needs. The NDAG meets twice yearly, and at each meeting the group reviews the data needs of the CS community, prioritizes those needs, and reviews the status of ongoing NCSP efforts to fulfill those needs. The fruit of this NDAG effort is tabulated in a document entitled "Nuclear Data Needs." This table, together with a second table entitled "Potential Materials by Application for

${ }^{a}$ Presenting author, e-mail: rdmcknight@anl.gov
NDAG Review and/or Utilization of NCSP Nuclear Data Infrastructure-Supported Resources," is published annually as Appendix D in the US DOE Nuclear Criticality Safety Program Five-Year Plan (http://ncsc.llnl.gov:8080/). The latest published version of this Nuclear Data Needs table, revised at the November 2006 NDAG meeting, is available at that website.

\section{Rationale for determining data needs}

Within the NCSP, data needs are identified by application. That is, a user within the criticality safety community has an application utilizing material $m$ and (step1) reports a "data" need for this material. This requested $\overline{\text { need }}$ can be of various types. For example, it may be for integral data to validate the methods and nuclear data used to analyze this application. Or it may request evaluated nuclear data for material $m$ or it constituents. Or it may even be requesting a need for a new method, formalism, or code to processes data for material $m$, such as thermal scattering data or covariance data.

We review now the subsequent steps in identifying and satisfying the requested need, considering for the moment that the requested need is for evaluated nuclear data. (As will be seen in the following discussion, this process or succession of steps does, in fact, determine the data need regardless of the type of request.) Step 2 in this process is to identify available relevant (and good quality) benchmarks. If relevant benchmarks are available, then analysis of these benchmarks identifies the validity or invalidity of the need for improved evaluated nuclear data for material $m$ (i.e., C/E's not close to $1.0)$ or not $(\mathrm{C} / \mathrm{E}$ 's close to 1.0$)$. In the former case with $\mathrm{C} / \mathrm{E}$ 's $\neq$ 1.0, this determination proceeds to step 4 (discussed below); in the latter case with $\mathrm{C} / \mathrm{E}$ 's $\approx 1.0$, it has been demonstrated that there is not a need to improve the evaluated nuclear data for material $m$.

The unavailability of relevant benchmark data for material $m$ leads to step 3 in this process, which is to identify existing integral experiments. If relevant integral experiment data are available, then the need is for new benchmark evaluations 
of these data. Otherwise, if relevant integral data are not available, then the need is to perform the "appropriate" integral experiments, where "appropriate" indicates integral experiments of good quality which have sufficient sensitivity to the nuclear data of material $m$ in the energy region of interest to the application requesting the data. After which the new integral data would be benchmarked and used to test the performance of the evaluated data for material $\mathrm{m}$. As before, if testing of this benchmark data indicates good performance then it is demonstrated there is no need for improved nuclear data for material $m$.

And if testing of this benchmark data indicates poor performance and a need for improved evaluated nuclear data for material $m$, then step 4 is to identify the availability and quality of the existing evaluated nuclear data files for this material. First the availability of quality differential experimental data in the energy region of interest (requisite to perform a quality data evaluation) is assessed. If such differential data are available, then a new evaluation of the data is performed and then tested as described above. If such differential data are not available, then it has been determined that the appropriate differential cross section measurements are required to meet the data needs for material $m$.

The above description of the rationale (steps 1-4) for determining data needs has been implemented within the NCSP to address user needs within the CS community and to allocate the proper resources within the NCSP infrastructure to meet those needs. The first of these steps is not only the simplest step, but also by far the most important step in this determination process - not only because it is the condicio sine qua non or essential condition, but also because it comes directly from and supports the criticality safety community. For the same reason the first step is by far the most difficult step. That is, expertise within the NDAG membership can address the technical decisions which arise in the following steps 2, 3 and 4. But the essential and most valuable input to step 1 must be supplied from without, i.e., from the end users within the criticality safety community. Since the inception of the NDAG, solicitation of the data needs from applications within the criticality safety community has been its first priority.

\section{Current priority list of data needs}

As noted above the most current list of nuclear data needs, i.e., the product of the NDAG review of data needs performed in November 2006, is available on the NCSP website. Recent input from the user community has identified new applications with potentially new priority needs. Furthermore, the commitment to restart critical experiments within the NCSP by 2010 has made it a priority to identify now those integral experiments of most value to the CS community. These activities have collectively produced Spring 2007 input to the Nuclear Data Schedule presented in table 1 which will be reviewed at the June 2007 NDAG meeting. The priority data needs, presented at the top of table, are denoted by highlighting (shading on a grey scale). Distinctions between these priority data needs and the remainder (additional needs) are primarily that the latter group either have been or are being addressed or that they are not derived from applications within the CS community. A very detailed survey of the status of these priority nuclear data needs for criticality safety by D.L. Smith (ANL) is included in these proceedings [1].

It may be noted in table 1 that differential cross section measurements supported within NCSP feed into the subsequent evaluation, testing and eventual inclusion into the ENDF/B data files as denoted by the progression of nuclides from the upper left hand corner toward the lower right hand corner of this schedule. It may also be noted that some of these activities represent international collaborative activities, such as the recent measurement of resonance data for ${ }^{55} \mathrm{Mn}$ at the Institute for Reference Materials and Measurements (IRMM) in Geel and the explicit indication of integral measurements performed at the All Russian Institute of Technical Physics (VNIITF) and the Institut de Radioprotection et de Sûreté Nucléaire (IRSN) in Valduc.

\section{Past, present and future examples}

Of course we have not yet identified and satisfied all of the nuclear data needs for criticality safety operations at the various DOE sites - but we have identified a number of specific operations involving specific materials which exhibit calculational biases and/or have sufficient nuclear data sensitivities that uncertainty reductions in those data are a priority. Improved data for these materials can lead to reduced uncertainties and reduced margins yielding reduced costs. Successful completed and on-going examples of improved nuclear data for nuclides of specific interest to the criticality safety can be cited.

\subsection{Previously on the priority list}

Some of the site projects that identified to the NDAG early details of their specific site operations included: Savannah River H-Canyon Processing of Waste Plutonium Solution; Savannah River Receipt and Storage of Hanford $\mathrm{U}$ and $\mathrm{Pu}$ Oxides and Metals Mixed with Beryllium; the Hanford Plutonium Finishing Plant (PFP); and Idaho National Laboratory (INL) Fuel and Fissile Material Storage and Shipping.

The Savannah River project involved processing plutonium solutions from $\mathrm{H}$-Canyon through the waste tank farm and eventually through the Defense Waste Processing Facility (DWPF). In order to assure subcriticality when the solutions are transferred to large waste tanks the solution was to be poisoned with gadolinium $(\mathrm{Gd})$. Other soluble poisons under consideration were iron (Fe) and manganese (Mn). When the solution was processed through the DWPF into glass logs, the moderator content drops and the neutron spectrum hardens thus reducing the effectiveness of the $\mathrm{Gd}$, which is a much stronger thermal neutron absorber. If $\mathrm{Fe}$ or $\mathrm{Mn}$ were to be used it would significantly increase the number of glass logs produced. The cost of each glass log was on the order of $\$ 100 \mathrm{~K}$; and the ability to show Gd was a useful nuclear poison in the DWPF and in the resulting glass logs with the higher energy neutron flux might have reduced the number of glass logs needed by 10-20\% compared to using alternative nuclear poisons. 
Table 1. Nuclear data schedule for the NCSP (Spring 2007).

\begin{tabular}{|c|c|c|c|c|c|}
\hline \multicolumn{2}{|c|}{$\begin{array}{c}\text { NDAG Review: } \\
\text { Needs / Additional Needs }\end{array}$} & $\begin{array}{l}\text { Thermal sc } \\
{ }^{239} \mathrm{Pu}, \mathrm{Cr},\end{array}$ & $\begin{array}{l}\text { attering }\left(\mathrm{BeO}, \mathrm{HF}, \mathrm{D}_{2} \mathrm{O}, \mathrm{S}\right. \\
{ }^{237} \mathrm{~Np}, \mathrm{~Pb}, \mathrm{~W},{ }^{55} \mathrm{Mn} \\
{ }^{233} \mathrm{U}, \mathrm{Th}, \mathrm{Be},{ }^{63} \mathrm{Cu},{ }^{65} \mathrm{Cu}\end{array}$ & $\begin{array}{l}\mathrm{iO}_{2}, \mathrm{CH}_{2}, \mathrm{C}_{2} \mathrm{~F}_{4}, \mathrm{C}_{5} \mathrm{O}_{2} \mathrm{H}_{8}, \\
\mathrm{Ti},{ }^{240} \mathrm{Pu}, \mathrm{Fe},{ }^{58} \mathrm{Ni} \\
{ }^{51} \mathrm{~V}, \mathrm{Zr}, \mathrm{F}, \mathrm{K}, \mathrm{Ca}\end{array}$ & $\begin{array}{l}\text { etc.), } \\
{ }^{60} \mathrm{Ni} /\end{array}$ \\
\hline Activity & FY 2007 & FY 2008 & FY 2009 & FY 2010 & FY 2011 $^{\dagger}$ \\
\hline $\begin{array}{l}\text { Differential } \\
\text { Measurements } \\
\text { (ORNL) }\end{array}$ & $\begin{array}{l}{ }^{58} \mathrm{Ni},{ }^{60} \mathrm{Ni}, \\
{ }^{63} \mathrm{Cu},{ }^{65} \mathrm{Cu}, \\
{ }^{52} \mathrm{Cr},{ }^{53} \mathrm{Cr}\end{array}$ & $\begin{array}{l}{ }^{240} \mathrm{Pu},{ }^{237} \mathrm{~Np}, \mathrm{Ti}, \mathrm{Be}, \\
\mathrm{Ca},{ }^{51} \mathrm{~V}, \mathrm{~W}, \text { assess } \\
\text { thermal scatt }(\mathrm{HF}, \\
\left.\mathrm{SiO}_{2}\right)\end{array}$ & $\begin{array}{l}\mathrm{Li} \text {, thermal scatt (HF, } \\
\left.\mathrm{SiO}_{2}\right)\end{array}$ & $\begin{array}{l}\text { Assess }{ }^{185} \mathrm{Re},{ }^{187} \mathrm{Re}, \\
{ }^{56} \mathrm{Fe}, \mathrm{Zr} \text {, thermal scatt } \\
\text { data }\end{array}$ & $\begin{array}{l}\text { Possibly higher } \\
\text { actinides if priority } \\
\text { for reprocessing }\end{array}$ \\
\hline $\begin{array}{l}\text { Integral } \\
\text { Measurements } \\
\text { (LANL) }\end{array}$ & \begin{tabular}{l} 
Sub-Criticals: $\mathrm{CH}_{2}$ \\
\hdashline $\mathrm{Ti}, \mathrm{V}(\mathrm{VNIITF})$ \\
$\mathrm{Pu}$ solns, $\mathrm{Al}, \mathrm{Cu}$, \\
$\mathrm{Fe}, \mathrm{Ni}, \mathrm{Pb}, \mathrm{Zr}, \mathrm{SiO}_{2}$ \\
$(\mathrm{IRSN})$
\end{tabular} & \begin{tabular}{l} 
Sub-Criticals: \\
$\mathrm{C}_{5} \mathrm{O}_{2} \mathrm{H}_{8, \mathrm{Ni}} \mathrm{Ni}$ \\
\hdashline$T B D=(\mathrm{VNITTF})$ \\
\hdashline$T B D($ IRSN $)$
\end{tabular} & $\begin{array}{l}\text { Sub-Criticals: } \\
\text { W, Cu }\end{array}$ & $\begin{array}{l}\text { Sub-Criticals: } \\
\mathrm{Pb},{ }^{55} \mathrm{Mn}, \mathrm{Ca}, \mathrm{Zr}, \mathrm{Mo} \\
\text { Criticals: HEU } \\
\text { spherical lattice, V } \\
\text { foils, V plates }\end{array}$ & $\begin{array}{l}\text { Sub-Criticals: } \\
\text { TBD } \\
\text { Criticals: UPF } \\
\text { Borabond \& } \\
\text { ES3100, Flattop } \\
\text { gap experiment } \\
\end{array}$ \\
\hline Evaluation & $\begin{array}{l}\text { ORNL: }{ }^{55} \mathrm{Mn} \text { (RR), } \\
{ }^{239} \mathrm{Pu}(\mathrm{RR}, \mathrm{UR}), \\
{ }^{39} \mathrm{~K},{ }^{40} \mathrm{~K},{ }^{41} \mathrm{~K}, \\
\mathrm{LANL}:{ }^{235} \mathrm{U} \\
\text { (inelastic), Np } \\
\text { (capture \& fission) }\end{array}$ & $\begin{array}{l}\text { ORNL: } \\
{ }^{58} \mathrm{Ni},{ }^{60} \mathrm{Ni},{ }^{63} \mathrm{Cu},{ }^{65} \mathrm{Cu} \\
(\mathrm{RR}),{ }^{52} \mathrm{Cr},{ }^{53} \mathrm{Cr}, \\
{ }^{55} \mathrm{Mn} \text { (UR), thermal } \\
\text { scat. graphite, } \\
\text { LANL: }{ }^{51} \mathrm{~V} \text {, Ti } \\
\text { isotopes }\end{array}$ & $\begin{array}{l}\text { ORNL: } \\
{ }^{58} \mathrm{Ni},{ }^{60} \mathrm{Ni},{ }^{63} \mathrm{Cu},{ }^{65} \mathrm{Cu} \\
\text { (UR); }{ }^{237} \mathrm{~Np}, \mathrm{Ti}, \\
{ }^{240} \mathrm{Pu}, \mathrm{Be}, \mathrm{Ca},{ }^{51} \mathrm{~V} \\
(\mathrm{RR}) \\
\text { LANL: }{ }^{240} \mathrm{Pu},{ }^{16} \mathrm{O}, \\
{ }^{55} \mathrm{Mn}\end{array}$ & $\begin{array}{l}\text { ORNL: }{ }^{237} \mathrm{~Np}, \mathrm{Ti}, \\
{ }^{240} \mathrm{Pu}, \mathrm{Be}, \mathrm{Ca},{ }^{51} \mathrm{~V} \\
\text { (UR) } ; \mathrm{Li},{ }^{138} \mathrm{Ce} \\
{ }^{140} \mathrm{Ce},{ }^{142} \mathrm{Ce}(\mathrm{RR}) \\
\text { LANL: W isotopes }\end{array}$ & $\begin{array}{l}\text { ORNL: } \mathrm{Zr} \\
\text { isotopes } \\
\text { LANL: } \mathrm{Cu}, \mathrm{Be}\end{array}$ \\
\hline $\begin{array}{l}\text { Covariance } \\
\text { Generation } \\
\text { (New evals and } \\
\text { retroactive } \\
\text { covariance } \\
\text { generation) }\end{array}$ & $\begin{array}{l}\text { ORNL: }{ }^{55} \mathrm{Mn},{ }^{39} \mathrm{~K}, \\
{ }^{40} \mathrm{~K},{ }^{41} \mathrm{~K},{ }^{19} \mathrm{~F}(\mathrm{RR}), \\
{ }^{235} \mathrm{U},{ }^{238} \mathrm{U}, \\
{ }^{239} \mathrm{Pu}(\mathrm{UR}) \\
\text { LANL: }{ }^{233} \mathrm{U} \\
\text { Multi-Lab: Lo- } \\
\text { Fidelity Cov Files }\end{array}$ & $\begin{array}{l}\text { ORNL: } \\
\begin{array}{l}{ }^{58} \mathrm{Ni},{ }^{60} \mathrm{Ni},{ }^{63} \mathrm{Cu},{ }^{65} \mathrm{Cu} \\
(\mathrm{RR}),{ }^{52} \mathrm{Cr},{ }^{53} \mathrm{Cr}, \\
{ }^{55} \mathrm{Mn} \text { (UR) } \\
\text { LANL: Ti isotopes }\end{array}\end{array}$ & $\begin{array}{l}\text { ORNL: } \\
{ }^{58} \mathrm{Ni},{ }^{60} \mathrm{Ni},{ }^{63} \mathrm{Cu},{ }^{65} \mathrm{Cu} \\
\text { (UR); }{ }^{237} \mathrm{~Np}, \mathrm{Ti}, \mathrm{Be}, \\
\mathrm{Ca},{ }^{51} \mathrm{~V}(\mathrm{RR}), \mathrm{W} \\
\text { LANL: }{ }^{240} \mathrm{Pu},{ }^{16} \mathrm{O}, \\
\\
{ }^{51} \mathrm{~V},{ }^{55} \mathrm{Mn}\end{array}$ & $\begin{array}{l}\text { ORNL: }{ }^{237} \mathrm{~Np}, \mathrm{Ti}, \\
{ }^{240} \mathrm{Pu}, \mathrm{Be}, \mathrm{Ca},{ }^{51} \mathrm{~V} \\
(\mathrm{UR}) ; \mathrm{Li},{ }^{138} \mathrm{Ce} \\
{ }^{140} \mathrm{Ce},{ }^{142} \mathrm{Ce}(\mathrm{RR}) \\
\text { LANL: W isotopes }\end{array}$ & $\begin{array}{l}\text { ORNL: } \mathrm{Zr} \\
\text { isotopes } \\
\text { LANL: } \mathrm{Cu}, \mathrm{Be}\end{array}$ \\
\hline $\begin{array}{l}\text { ENDF Evals } \\
\text { delivered to } \\
\text { NNDC }\end{array}$ & $\begin{array}{l}{ }^{19} \mathrm{~F},{ }^{39} \mathrm{~K},{ }^{40} \mathrm{~K},{ }^{41} \mathrm{~K}, \\
{ }^{233} \mathrm{U},{ }^{235} \mathrm{U},{ }^{237} \mathrm{~Np}, \\
{ }^{239} \mathrm{Pu}, \mathrm{Be}, \\
{\left[{ }^{234} \mathrm{U}(\mathrm{CRP})\right]}\end{array}$ & $\begin{array}{l}\text { ORNL: }{ }^{55} \mathrm{Mn}, \\
{ }^{52} \mathrm{Cr},{ }^{53} \mathrm{Cr} \\
\text { LANL: }\end{array}$ & $\begin{array}{l}\text { ORNL: } \\
{ }^{58} \mathrm{Ni},{ }^{60} \mathrm{Ni},{ }^{63} \mathrm{Cu},{ }^{65} \mathrm{Cu} \\
\text { LANL: }{ }^{240} \mathrm{Pu},{ }^{55} \mathrm{Mn}, \\
{ }^{16} \mathrm{O},{ }^{51} \mathrm{~V}\end{array}$ & $\begin{array}{l}\text { ORNL: }{ }^{237} \mathrm{~Np}, \mathrm{Ti}, \\
{ }^{240} \mathrm{Pu}, \mathrm{Be}, \mathrm{Ca},{ }^{51} \mathrm{~V} \\
\text { LANL: } \mathrm{W} \text { isotopes }\end{array}$ & $\begin{array}{l}\text { ORNL: } \mathrm{Zr} \\
\text { isotopes } \\
\text { LANL: } \mathrm{Cu}, \mathrm{Be}\end{array}$ \\
\hline $\begin{array}{l}\text { CSEWG } \\
\text { Testing }\end{array}$ & $\begin{array}{l}\text { ENDF/B-VII.0 } \\
\text { evaluations, } \\
\text { including } \\
\text { covariance data }\end{array}$ & $\begin{array}{l}\text { Beta Versions of - } \\
\text { VII.1 evaluations, } \\
\text { including covariance } \\
\text { data }\end{array}$ & $\begin{array}{l}\text { Beta Versions of - } \\
\text { VII.1 evaluations, } \\
\text { including covariance } \\
\text { data }\end{array}$ & $\begin{array}{l}\text { Beta Versions of - } \\
\text { VII.1 evaluations, } \\
\text { including covariance } \\
\text { data }\end{array}$ & $\begin{array}{l}\text { Beta Versions of - } \\
\text { VII.1 evaluations, } \\
\text { including } \\
\text { covariance data }\end{array}$ \\
\hline $\begin{array}{l}\text { Processed } \\
\text { Libraries }\end{array}$ & $\begin{array}{l}\text { ENDF/B-VII.0 } \\
\text { distributed; Beta } \\
\text { Versions of -VII.1 }\end{array}$ & $\begin{array}{l}\text { Beta Versions of - } \\
\text { VII.1 }\end{array}$ & $\begin{array}{l}\text { Beta Versions of - } \\
\text { VII.1 }\end{array}$ & $\begin{array}{l}\text { Beta Versions of - } \\
\text { VII.1 }\end{array}$ & $\begin{array}{l}\text { Beta Versions of - } \\
\text { VII.1 }\end{array}$ \\
\hline
\end{tabular}

The Hanford Plutonium Finishing Plant (PFP) is a closure facility dependent upon being able to package and ship various fissile wastes to Savannah River to support closure and cleanup milestones. PFP planned to ship uranium and plutonium oxides and metals in a beryllium matrix to Savannah River.

The PFP program objectives are to stabilize fissile material, package the material for off site and on site shipment, and Decontaminate and Decommission (D \& D) the facility. To expedite the process within the existing criticality safety requirements necessitates availability of improved nuclear data, additional experiments, the use of fixed neutron absorbers, and possible in situ measurements. Improved knowledge of the following cross sections: $\mathrm{Cl}, \mathrm{Fe}, \mathrm{Ni}, \mathrm{Mn}, \mathrm{Cr}, \mathrm{Si}$, $\mathrm{Ce}$ and $\mathrm{Ca}$ are needed to improve criticality safety margins for nuclear operations.

Of particular interest to the INEEL is whether existing critical experimental data are adequate to validate systems with discrete steel, i.e., fuel stored in a thick stainless steel can or insert. The steel acts as a mild absorber and can reduce the overall reactivity of the system allowing increased fuel density. 
These specific site operations identified priority data needs for $\mathrm{Gd}, \mathrm{Be}, \mathrm{Cl}, \mathrm{Si}, \mathrm{Ce}, \mathrm{Ca}$, and the constituents of stainless steel $(\mathrm{Fe}, \mathrm{Ni}, \mathrm{Cr}, \mathrm{Mn})$. The new ENDF/B-VII.0 data files [2] contain new evaluations of $152,153,154,155,156,157,158,160 \mathrm{Gd}$, ${ }^{35,37} \mathrm{Cl},{ }^{28,29,30} \mathrm{Si},{ }^{136,138,139,140,141,142,143,144} \mathrm{Ce},{ }^{40,42,43,44,46,48} \mathrm{Ca}$; and a new ${ }^{9} \mathrm{Be}$ evaluation is expected this year. Several of the constituents of steel are in progress $\left({ }^{55} \mathrm{Mn}\right)$ or planned (isotopes of $\mathrm{Ni}$ and $\mathrm{Cr}$ ).

\subsection{Current and future priorities}

The impact of the titanium cross sections and uncertainties on the criticality safety of the Actinide Removal Process (ARP) facility at the Savannah River Site (SRS) has recently been identified as a new priority. Recent work by Leal et al. [3], including results of sensitivity analysis using the ENDF/BVII.0 titanium data and a new evaluation of covariance data for ${ }^{48} \mathrm{Ti}$ are presented at this conference.

There is continued demand for covariance data. Although the initial release of ENDF/B-VII.0 contained very limited covariance data, these data, improved methodologies to produce these data, and improved methodologies to check and process these data are a high priority to the NCSP. It should be expected that these methods and these data will continue to be produced and to improve over the next several years.

Another priority need for the CS community which is now beginning to be address is the general need for thermal scattering data for a wide range of common moderator materials, such as Lucite, $\mathrm{C}_{5} \mathrm{O}_{2} \mathrm{H}_{8}, \mathrm{CH}_{2}, \mathrm{C}_{2} \mathrm{~F}_{4}, \mathrm{BeO}, \mathrm{HF}, \mathrm{D}_{2} \mathrm{O}$, $\mathrm{SiO}_{2}$, etc. Furthermore, if current studies to consider advance fuel reprocessing lead to actual construction and operation of these facilities, this will add a number of additional processing chemicals to the list of materials for which we have no thermal scattering data. As noted for the covariance data, it should be expected that methods to evaluate these scattering data and the data will receive increased attention and continue to be produced and to improve over the next several years.

\section{Conclusions}

Within the US Nuclear Criticality Safety Program there has been an increased awareness and a renewed effort to identify and to address the nuclear data needs arising from site operations throughout the DOE complex. The effect has been to focus the limited available resources more directly on data improvements which support DOE missions, reduce safety risks and reduce costs.

Work supported by the US Department of Energy, Nuclear Criticality Safety Program under Contract DE-AC02-06CH11357.

\section{References}

1. D.L. Smith, A Survey of the Status of Nuclear Cross Section Data for Criticality Safety (these proceedings).

2. M.B. Chadwick et al., ENDF/B-VII.0: Next Generation Evaluated Nuclear Data Library for Nuclear Science and Technology, Nucl. Data Sheet 107, No. 12 (Dec. 2006).

3. L. Leal et al., Assessment of Titanium Cross Sections and Uncertainties for Application in Criticality Safety, in Proceedings of The 8th International Conference on Nuclear Criticality Safety, May 28-June 1, 2007, St. Petersburg, Russia (to be published). 